\title{
Socio Demographic Factors Influencing the Income of Native Chicken Farming in Rural Area of Ciamis Regency
}

\author{
Lucie Setiana*, Mochamad Sugiarto and Oentoeng Edy Djatmiko \\ Faculty of Animal Science, Jenderal Soedirman University, Purwokerto, Indonesia \\ *corresponding author: luciestiana@yahoo.com
}

\begin{abstract}
Sentul chicken is one of indigenous poultries maintained by most people in Ciamis Regency, West Java Province. This study aimed at determining the influence of socio demographic factors on the income generated from Sentul chicken farming in Ciamis Regency. A survey method was conducted to the members of seven farmer groups institutionally assisted by the Ciamis Regency Government Unit. The descriptive statistics and multiple linear regression analysis were used to describe the profile of respondents and to analyze the influence of socio demographic factors on the income generated from Sentul chicken farming. The results showed that the farmers' length of education was 11.8 years with 5.8 years experience raising the Sentul chicken while the farm size was averagely 9 heads of chicken. The Sentul chicken farm maintained in 70 days with semi-intensive production system has generated income ranging from IDR 756,000 to IDR 19,900,000. Farming experience and farm size significantly influenced the income generated from Sentul chicken farming. Increase the farming experience of Sentul chicken farmers and enlarging Sentul chicken farm size with semi-intensive production system may improve the income generated from Sentul chicken farming in Ciamis Regency.
\end{abstract}

Keywords: sentul chicken, farm size, farming experience, income

Abstrak. Ayam sentul merupakan salah satu unggas asli yang dipelihara oleh sebagian besar masyarakat di Kabupaten Ciamis, Propinsi Jawa Barat. Penelitian ini bertujuan untuk mengetahui pengaruh faktor sosial demografi terhadap pendapatan yang dihasilkan dari usaha peternakan ayam Sentul di Kabupaten Ciamis. Metode survei dilakukan terhadap anggota kelompok peternak yang secara kelembagaan dibantu oleh Pemerintah Kabupaten Ciamis. Statistik deskriptif dan analisis regresi linier berganda digunakan untuk menggambarkan profil responden dan menganalisis pengaruh faktor sosio demografis terhadap pendapatan yang dihasilkan dari usaha peternakan ayam Sentul. Hasil penelitian menunjukkan bahwa lama pendidikan peternak adalah 11,8 tahun dengan pengalaman beternak ayam Sentul 5,8 tahun, sedangkan rataan skala usaha sebanyak 9 ekor ayam. Usaha ternak ayam Sentul dilakukan dalam 70 hari setiap periode dengan sistem produksi semi intensif dan menghasilkan pendapatan dengan kisaran mulai dari Rp756.000,00 sampai Rp19.900.000,00. Pengalaman beternak dan skala usaha secara signifikan mempengaruhi pendapatan yang dihasilkan dari usaha peternakan ayam Sentul. Meningkatkan pengalaman beternak ayam Sentul dan memperbesar skala usaha peternakan ayam Sentul dengan sistem produksi semi intensif dapat meningkatkan pendapatan yang dihasilkan dari usaha peternakan ayam Sentul di Kabupaten Ciamis.

Kata kunci: ayam sentul, skala usaha, pengalaman beternak, pendapatan

\section{Introduction}

Rural development cannot be separated from efforts to improve community welfare carried out by increasing employment opportunities. The availability of employment opportunities in rural areas is believed to increase household food consumption and economic performance. Abdullah et al. (2019) stated that the unavailability of employment opportunities will cause household food insecurity. The development of local chicken farming in rural areas is believed to increase community involvement in rural economic activities that has impact on strengthening household economic conditions. Hidayat and Asmarasari (2015) stated that native chicken represents one of the few opportunities for saving, investment and security against risk. Sentul Chicken is one of local genetic resources found in Ciamis Regency of West Java Province maintained in a semi-intensive 
method and has an important role to increase the family income. Mugiyono et al. (2015) stated that Sentul chicken has relatively faster body growth and higher egg production than those of other local chickens. These situations would become opportunities for greater development on an industrial scale of Sentul chicken.

In Ciamis Regency, Sentul chicken is widely maintained by the people as the local food sources of meat and egg supply in the countryside. In addition, the increasing number of food and restaurant businesses which use chicken meat as their raw materials also increase the demands for Sentul chickens. The greater the potential demands for Sentul chickens may open more opportunities to increase the availability and production. However, the limited scale of business, land, business orientation, and capital availability are the main characteristics of the Sentul chicken production system in Ciamis Regency. The presence of the government's role in strengthening the Sentul chicken business has become very important through systematic coaching and changing business orientation towards a larger scale. The role of the government through farmers groups is believed to be able to improve production performance and welfare of local chicken farmers. Real conditions show that many local chickens are kept extensively without the involvement of farmers and government. Mahoro et al. (2017) described that the local chicken production system is mostly carried out extensively with a minimum provision of supplementary feeds. Establishing and strengthening the Sentul chicken farmer groups were conducted in response to the increasing market potential. The management of the Sentul chicken farming is carried out with significant attention and intervention from the Government of Ciamis Regency through forming farmer groups. Farmer group members are encouraged to be able to conduct activities well and efficiently to increase the farmers' income. Through farmers' groups, members can exchange information related to diseases, feed, and poultry breeding. Farmer groups have a strategic role in increasing the capacity of farmers to access information. Msoffe and Ngulube (2016) stated that farmers really prioritize accessing information related to disease control, poultry protection, breeds and breeding, and feeding and nutrition. Farmers relied on informal sources of information, mainly from family, friends, neighbours, extension officers, researchers, and radio.

Through farming groups, the members can exchange information related to disease, feed and breeding of Sentul chicken. Farmers group has strategic role on improving farmer's capacity in accessing information. Msoffe and Ngulube (2016) stated that farmers prioritize accessing information related to disease control, poultry protection, breeds and breeding, and feeding and nutrition. Farmers relied on informal sources of information, mainly from family, friends, neighbors, extension officers, researchers, and radio. However, the farmers' backgrounds are considerably various in terms of age, education, farming experience and farm size. These factors need more attention to strengthen the Sentul chicken farming's efficiency and the farmers' income maintained using a semi-intensive method. Therefore, this study examines the farmers' income related to the Sentul chicken farming maintained with a semi-intensive method and the influence of various social demographic factors on the income generated from Sentul chicken farming.

\section{Materials and Methods}

In 2017, there were 6 groups of Sentul chicken farmers that were active in planning, implementing, evaluating group activities and 
spread in 5 sub-districts. Research on identifying socio-demographic factors that affect the income of Sentul chickens farming in Ciamis Regency was conducted using a survey method with questionnaires distributed to 41 Sentul chicken farmers. The number of respondents was selected using a random sampling method from 6 Sentul chicken farmer groups spread in 5 districts of Ciamis Regency. Each farmer group consists of 20-30 members and the respondents were selected randomly 30 percent of the total members in each farmer group.

The collected data were then analyzed using a descriptive statistic method to describe the social and demographic profile of the farmers and the income generated from the Sentul chicken farming. Income analysis was conducted to determine the income generated from Sentul chicken farming for 1 year of production with the following formula (Pawariya and Jheeba, 2015): I = TR - TC ( $I$ = income; $T R=$ Total Revenue (chicken sale and the other revenue). TR = Total Cost (fixed and variable costs)

Meanwhile, a multiple regression analysis is used to identify the influence of social demographic factors which consist of farmers' farming experience, farms size, and farmers' educational level on the income generated from Sentul chicken farming. The research model can be translated into a mathematical model: $Y=a+b_{1} x_{1}+b_{2} x_{2}+b_{3} x_{3}+e$.

$(Y=$ income generated from chicken Sentul farming; $X_{1}=$ farming experience; $X_{2}=$ farm size; $X_{3}=$ farmers' educational level )

\section{Results and Discussion}

Sentul chicken farming in Ciamis Regency is maintained by the farmer groups. Until 2017, there were 6 Sentul chicken farmer groups (Gemah Ripah, Anugerah, Taruna Guna Bakti, Kuntum Mekar, Ciung Wanara, and Karomah farmer group) spread in 5 districts: Banjarsari,
Sadananya, Tambaksari, Cijeungjing and Rancah.

\section{Profile of Respondents}

A total of 41 farmers with various social demographic backgrounds were selected as the research respondents. The Sentul chicken farmers in Ciamis Regency have an average age of 41.4 years which are still classified into a productive age. This condition is almost the same as local chicken farmers in the Philippines who are in productive age with an average of 43.3 years (Lopez et al., 2014). This condition is better than local chicken farmers who carry out extensive activities and domination by older age farmers (Ojo, 2009). The semi-intensive maintenance pattern required the greater farmers' intervention than the extensive one. This condition requires greater attention in terms of time and knowledge that younger farmers at their productive age highly conform to the characteristics of semi-intensive patterns. Farmers' age determines their decisions on selecting the type of local chicken to maintain (Teklewold et al., 2006). Younger farmers will thoroughly consider the economic benefits when selecting the type of local chicken. Sentul chicken farmers in Ciamis Regency had experienced ranging from 1 - 11 years in raising the local chicken. Most farmers (31 percent) had the local chicken farming experience ranging from 4 to 7 years. The experience of Sentul chicken farmers provides a better picture of farmers' attitudes and behaviors with a commercial orientation through the development of farmers groups by the Ciamis Regency government.

Sentul chicken farmers generally did not have any farming activity before becoming the members of Sentul chicken farmer groups. The farmers have become the farmer group members as assisted by the Local Government of Ciamis Regency. Although previously lack of expertise in raising local chickens, the longer 
the involvement of Sentul chicken farmer groups, the greater the farmers are helped to overcome their difficulties related to the Sentul chicken farming. Farmers, with farming experiences for a long time, will have more knowledge to facilitate their farming. The number of Sentul chickens maintained by the members of Sentul chicken farmer groups in Ciamis Regency conducted with semi-intensive varied greatly, ranging from $100-4000$ chickens. The farm size ownership varies greatly due to the limited land, family labour, and capital belonging to the farmers. The numbers of local chicken maintained with a semi-intensive pattern is relatively larger than the extensive pattern. Hailemichael et al. (2017) illustrate that the maintenance of freerange native chicken in rural Ethiopia is only at an average of 14 chickens.

Sentul chicken farmers in Ciamis Regency have a formal education at an average of 14 years or equivalent to senior high school graduates. This condition is in line with the study Wantasen et al. (2014) which also states that the most indigenous chicken farmers in North Sulawesi were graduated from senior high schools. Thus, it is expected that they may increase their insight and knowledge to well maintain the Sentul chicken farming. Sufficient education and training experience may open the farmers' horizons of knowledge on technical and economic principles that the farmers may well understand the poultry management and become successful in poultry farming (Ibitoye and Onimisi, 2013).

\section{Income Generated from Sentul Chicken Farming}

Sentul chicken farming income analysis was conducted to describe the income generated from Sentul chicken farming with a semiintensive pattern. The analysis on Sentul chicken farming income for meat-producing purposes semi-intensively maintained with a period of 70 days was calculated from the ready-to-market pullets. In this study, the income generated fromsentul chicken farming varies widely, ranging from IDR $756,000 /$ period to IDR $19,900,000 /$ period. The calculation results show the average net income per period (70 days) is IDR 4,000,141.

Income analysis is generated from the difference between total revenue and total production costs (costs of seeds, feed, vaccines, employees, transportation and electricity). Revenue is obtained by the farmers from the sale of ready-to-slaughter

Table 1. Sentul chicken farming income analysis

\begin{tabular}{|c|c|c|c|}
\hline No & Cost Components & IDR & Percentage \\
\hline A & Costs & & \\
\hline \multirow[t]{7}{*}{1} & Variable Costs & & \\
\hline & Pullet & $3,573,415$ & 32.90 \\
\hline & Feed & $6,440,273$ & 59.30 \\
\hline & Medicine & 78,049 & 0.72 \\
\hline & Labor & 426,829 & 3.93 \\
\hline & Transportation & 46,537 & 0.43 \\
\hline & Sub Total & $10,565,103$ & \\
\hline \multirow[t]{3}{*}{2} & Fixed Cost & & \\
\hline & Electricity & 295,732 & 2.72 \\
\hline & Sub Total & 295,732 & \\
\hline 3 & Total Cost & $10,860,835$ & 100 \\
\hline B & Revenue & & \\
\hline 1 & chicken Sale & $14,843,415$ & 99.88 \\
\hline \multirow[t]{2}{*}{2} & Other revenue & 17,561 & 0.12 \\
\hline & Total revenue & $14,860,976$ & 100 \\
\hline C & Income & $4,000,141$ & \\
\hline
\end{tabular}


chickens weighing $0.8-1.2 \mathrm{~kg}$. Income generated from Sentul chicken farming is from the chicken sale which is influenced by the number of chickens and the chicken selling price (Sudrajat and Isyanto, 2018).

\section{The Influence of Socio Demographic Factors on Income generated from Sentul Chicken Farming}

Efforts to increase the income generated from Sentul chicken farming are an important concern in increasing the family's economic resilience. The farmers' various social demographic conditions must be an important issue to study in the framework of increasing the farm income. Sentul chicken farming sustainability is also associated with the farmers' economic motivations. Their success to increase the farm income may have a positive impact on their farming sustainability.

Based on the multiple regression analysis as presented in Table 2, the income generated from Sentul chicken farming may be well explained by the equation $Y=9.083+0.113 X_{1}$ $+0.955 X_{2}+0.001 X_{3}$ with $R^{2}$ of 0.983 which means that the income generated from Sentul chicken farming is significantly explained by the farming experience, farm size, and farmers' education $(P<0.01)$. The farmers' social and demographic characteristics contributed 98.3 percent to the income changes generated from Sentul chicken farming. Partially, it is understood that the farmers' experience in raising the local chicken and the number of Sentul chickens have a significant influence $(P<0.05)$ on the income generated from Sentul chicken farming. Increasing the farmers' experience in raising Sentul chicken and the number of Sentul chickens positively influenced the farming income. The longer the farmers involved in Sentul chicken farming the better the farmers' understanding on problems related to Sentul chicken farming that they were able to anticipate and solve the arising problems. Adequate experience may encourage the farmers to efficiently and productively do businesses. Farming experience gave a positive influence on the income increase generated from the local chicken farming in rural areas of Africa (Oladuni and Fatuase, 2014). The number of maintained Sentul chickens greatly influences the number of sales to the costumers or markets. The increasing number of maintained chickens has an impact on the increasing number of sales which ultimately can increase the revenue and income generated from Sentul chicken farming. It mentions that farm size and income are positively related. It means that the respondents with larger farms may generate more income. The larger the farming scale the better the farmers' welfare or the greater the number of poultries maintained in one period, the higher the income may be received by farmers (Istikomah et al., 2010). Increasing the scale of Sentul chicken farming has an impact on efficiency to the use of production factors, such as the fixed costs imposed on the increasing number of Sentul chicken that the production costs per production unit will be smaller.

Table 2. The influence of farming experience, farm size, and education on income generated from Sentul chicken farming conducted with a multiple regression analysis

\begin{tabular}{lccc}
\hline \multicolumn{1}{c}{ Variables } & $\mathrm{B}$ & $\mathrm{t}$ & Significance $(\mathrm{P})$ \\
\hline Constant & 9.083 & 54.439 & 0.001 \\
Farming experience $\left(\mathrm{X}_{1}\right)$ & 0.113 & 2.435 & $0.020^{*}$ \\
Farm size $\left(\mathrm{X}_{2}\right)$ & 0.955 & 46.882 & $0.001^{* *}$ \\
Farmers' educational level $\left(\mathrm{X}_{3}\right)$ & 0.001 & 0.007 & 0.994 \\
\hline
\end{tabular}

* Significant at level 0.05 ; ** Significant at level 0.01 


\section{Conclusions}

Improving income generated from Sentul chicken farming in Ciamis Regency may become a way to strengthen the family's economic resilience. The success in identifying the factors influencing the income generated from Sentul chicken farming may provide more contributions in strengthening the family's economic resilience. It is concluded that the farmers' experience in raising Sentul chickens and Sentul chicken farm size are important factors to increase the income generated from Sentul chicken farming in Ciamis Regency. It is suggested to Ciamis Regency Government to provide more effective trainings and comparative studies to the farmers that they are able to solve any arising problems and strengthen their innovations in chicken production. In addition, increasing the farm scale is required to be made by facilitating the Sentul chicken farmers with cooperatives, nucleus companies and financial institutions.

\section{References}

Abdullah, D. Zhou, T. Shah, S. Ali and W. Ahmad. 2019. Factors affecting household food security in rural northern hinterland of Pakistan. Journal of the Saudi Society of Agricultural Sciences 18 : 201-210.

Hailemichael, A., B. Gebremedhin and A. Tegegne. 2017. NJAS - Wageningen Journal of Life Sciences $83:$ 30-38.

Hidayat, C and S. A. Asmarasari. 2015. Native Chicken Production in Indonesia: A Review. Jurnal Peternakan Indonesia Vol 17 (1): 1-11.

Ibitoye S. J. and Onimisi JA. 2013. Influence of training on farmer's productivity in poultry production in Kogi State, Nigeria. Int J Poult Sci. $12(4): 239-44$.

Istikomah, Suhadi I, and Marhani. 2010. Analisis Pendapatan dan Elastisitas Produksi Usaha Ternak Ayam Kampung Pedaging Intensif di
Kecamatan Sangatta Utara dan Bengalon, Kabupaten Kutai Timur. J Pertan Terpadu Vol 6 (1):98-109.

Lopez, R. V., A. L. Lambio, R. S. A. Vega and A. P. O. De Guia. 2014. Management practices of native chicken (Gallus gallus domesticus Linn.) production in Palawan, Philippines. Philippine Journal of Veterinary and Animal Science 40(2):109-120.

Mahoro, J.,T. K. Muasya, F. Mbuza, R. Habimana and A. K. Kahi. 2017. Characterization of indigenous chicken production systems in Rwanda. Poultry Science 96:4245-4252.

Msoffe, G and P. Ngulube. 2016. Farmers' access to poultry management information in selected rural areas of Tanzania. Library \& Information Science Research 38: 265-271.

Mugiyono, S., D. M. Saleh and Sukardi. 2015. Reproductive Performance of Various Breeds of Sentul Chicken. Animal Production. 17(3):169176.

Ojo, S.O. 2009. Backyard Farming: A panacea for food security in Nigeria. J Hum Ecol, 28 (2): 127 $-133$.

Oladunni, M. E. and A. I. Fatuase. 2014. Economic Analysis of Backyard Poultry Farming in Akoko North West Local Government Area of Ondo State, Nigeria. G.J.B.A.H.S.,Vol.3(1):141-147.

Sudrajatand A. Y. Isyanto. 2018. Faktor-faktor yang Berpengaruh Terhadap Pendapatan Usaha Ternak Ayam Sentul di Kabupaten Ciamis. Mimb Agribisnis. 4 (1):70-83.

Teklewold, H., L. Dadi, A. Yami and N. Dana. 2006. Determinants of adoption of poultry technology: A double-hurdle approach. Livestock Research for Rural Development Vol. $18:$ 75-86.

Pawariya, V. and S. Jheeba. 2015. Economic Analysis of Costs-Return, Income and Employment in Poultry Enterprise in Jaipur District of Rajasthan State. International Journal of Agricultural Science and Research (IJASR) Vol. 5 (1): 73-80.

Wantasen, E., F. H. Elly and N. M. Santa. 2014. The analysis of semi intensive native chicken farming in rural communities: case study on farmers group "Poyuyanan" in Poyowa Besar Village, South Kotamobagu District, North Sulawesi Province. J Indones Trop Anim Agric. Vol 39:126-33. 